\title{
JIII
}

\section{Determinan Zakat Bank Umum Syariah di Indonesia}

\author{
Alwindi Santoso ${ }^{1}$, Wahyudi ${ }^{2}$ \\ ${ }^{1}$ Prodi Ekonomi Islam, Fakultas Ekonomi dan Bisnis, Untan, INDONESIA, email: \\ alwindisantoso@student.untan.ac.id \\ ${ }^{2}$ Fakultas Ekonomi dan Bisnis, Untan, INDONESIA, email: \\ awankyudi@yahoo.com
}

\begin{abstract}
ABSTRAK
Tujuan penelitian ini adalah untuk mengetahui pengaruh variabel-variabel yang menjadi penentu dalam pengeluaran zakat internal bank umum syariah di Indonesia. Adapun metode yang digunakan adalah metode regresi data panel dengan model yang terpilih adalah Fixed Effect Model (FEM) dengan pendekatan kuantitatif. Penelitian ini menguji pengaruh return on asset, return on equity, dan ukuran perusahaan pada 4 bank umum syariah, yaitu Bank Rakyat Indonesia Syariah, Bank Syariah Mandiri, Bank Muamalat, dan Bank Negara Indonesia Syariah. Hasil penelitian ini ditemukan bahwa secara parsial return on equity dan ukuran perusahaan berpengaruh signifikan terhadap zakat bank umum syariah. Namun, return on asset tidak berpengaruh signifikan terhadap zakat bank umum syariah. Sedangkan untuk hasil pengujian secara simultan return on asset, return on equity, dan ukuran perusahaan berpengaruh signifikan terhadap zakat bank umum syariah.
\end{abstract}

Kata kunci: Zakat; Bank Umum Syariah; Return On Asset; Return On Equity; Ukuran Perusahaan. 


\section{PENDAHULUAN}

Zakat bukan menjadi hal yang baru di Indonesia. Bahkan kewajiban zakat dikenakan baik setiap individu maupun organisasi badan usaha salah satunya zakat pada bank umum syariah. Undang-undang zakat di Indonesia No. 38/1999 pasal 11 ayat 2-point b dinyatakan bahwa "perdagangan dan perusahaan merupakan harta yang dikenai Zakat" sedangkan menurut syari'at harta yang diinvestasikan dalam syirkah dengan mengandalkan usaha dari manusia dengan tujua mencapai keuntungan dan pertumbuhan harta maka wajib dizakati. Zakat perusahaan sudah seharusnya menjadi kewajiban yang harus dikeluarkan sebagai bentuk kepatuhan perusahaan. Selain sebagai sarana ibadah akan mencapai kemaslahatan dan kerberkahan, zakat juga sebagai aspek tolong menolong perusahaan sebagai bukti kepedulian dan kewajiban yang harus dilakukan agar terciptanya keseimbangan dalam aktivitas kinerja (Kurniawan \& Suliyanto, 2014 dalam firmansyah 2013).

Kebijakan zakat dipengaruhi oleh berbagai faktor penentu baik faktor yang dapat dikendalikan dan tidak dapat dikendalikan. Pengeluaran zakat BUS sangat dipengaruhi kondisi perusahaan atau rasio profitabilitas perusahaan. Dengan mengamati kondisi rasio keuangan memberikan gambaran pemanfaatan sumber daya yang digunakan dalam menghasilkan laba atas ekuitas. Adapun rasio keuangan yang digunakan dalam penelitian ini yaitu Return On Asset (ROA) sebagai rasio untuk menilai suatu perusahan dalam laba bersih (Zaitun, 2001). Return on Equity (ROE) sejauh mana perusahaan dalam mempergunakan sumber daya dalam memberikan keuntungan atas ekuitas (Fahmi, 2012). Ukuran perusahaan yang digunakan sebagai informasi besar kecilnya perusahaan.

Beberapa peneliti sebelumnya juga meneliti mengenai zakat perusahaan diantaranya penelitian yang dilakukan Santoso (2019) dari uji t yang dilakukan bahwa ukuran perusahaan dan ROA berpengaruh terhadap zakat BUS dan secara simultan juga berpengaruh namun kemampuan pengaruh variabel yang digunakan terhadap pengeluaran zakat. Penelitian serupa juga dilakukan Maulana (2019) menemukan bahwa profitabilitas BUS yang yang terdiri dari ROA maupun ROE berpengaruh signifikan sedangkan ROOA tidak signifikan. Ukuran perusahaan hanya mampu memoderasi ROA dan ROE sedangkan untuk ROOA ukuran perusahaan belum mampu memoderasi. Penelitian lainnya dilakukan Widiastuti (2018) menemukan bahwa ROA tidak signifikan terhadap zakat BUS dan hanya ROE yang berpengaruh signifikan sedangkan ukuran perusahaan sudah mampu memoderasi.

Direktur Utama Baznas, M. Arifin Purwakanata (26/2), mengatakan "terdapat kewajiban untuk berzakat pada usaha baik secara perusahaan maupun lembaga". Selain itu M. Arifin menambahkan dalam acara seminar nasional zakat perusahaan bahwa "berdasarkan riset yang dilakukan antara Baznas bekerjasama dengan IRTIIDB dan IPB pada tahun 2011 potensi zakat sebesar 217 triliun, dan potensi total zakat perusahaan sebesar 111 triliun, namun kenyataannya zakat perusahaan belum menjadi wacana dikalangan pengusaha sehingga belum maksimal" (Republika.co.id, 26 Feb 2020). 


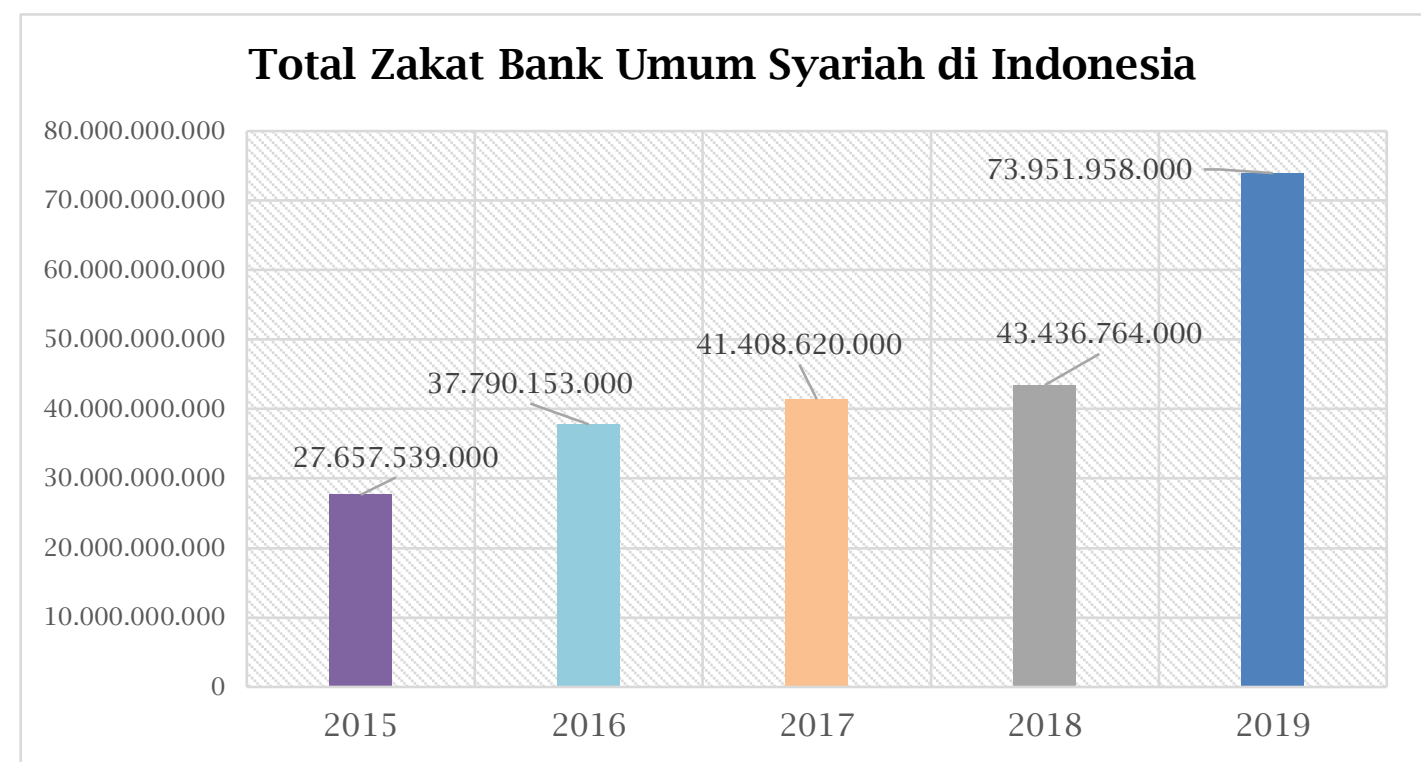

Gambar 1: Pengeluaran Zakat Internal Pada Bank Syariah di Indonesia Sumber: Laporan keuangan BUS di Indonesia

Berdasarkan data pada gambar 1 dapat disimpulkan bahwa pengeluaran zakat khusus dari BUS di Indonesia mengalami peningkatan setiap tahunnya. Akan tetapi pengeluaran zakat pada BUS tidak sebanding dengan total laba usaha pada periode yang sama sebagai pengukuran besarnya zakat yang harus dikeluarkan. Banyak BUS juga tidak melaporkan sumber zakat baik internal maupun zakat dari eksternal, dimana zakat eksternal menjadi dominasi dengan jumlah yang sangat besar. Pengeluaran zakat internal BUS hanya didominasi oleh empat BUS saja dari total 14 BUS di Indonesia. Keberadaan BUS seharusnya menjadi potensi zakat perusahaan dari sektor keuangan syariah. Namun kenyataannya zakat dari BUS tidak sebanding dengan pertumbuhan aset dan potensi zakat perusahaan karena ditemukan masih banyak BUS yang tidak mengeluarkan zakat khusus dari internal BUS.

Permasalahan yang dikaji dalam penelitian ini yaitu ditemukan fakta bahwa potensi zakat yang besar yang harus dikembangkan dari segala sektor. Pengeluaran zakat BUS sangat ditentukan oleh kondisi perusahaan. Namun, disisi lain ditemukan bahwa perbankan syariah yang kondisi keuangannya baik tidak sebanding dengan kemampuan untuk berzakat bahkan jumlahnya sangat minim. Selain itu sejumlah BUS sama sekali tidak megeluarkan zakat padahal laba usaha yang diperoleh sebagai ukuran wajib zakat telah mencapai wajib minimum. Secara teoritis sangat perlu mengkaji faktor penentu yang digunakan untuk melihat kondisi keuangan dari setiap bank umum syariah terhadap kemampuan zakat yang dikeluarkan. Tujuan dalam penelitian ini adalah (1) menganalisis pengaruh return on asset terhadap pengeluaran zakat pada bank umum syariah di Indonesia, (2) menganalisis mengetahui pengaruh return on equity terhadap pengeluaran zakat pada bank umum syariah di Indonesia, dan (3) menganalisis pengaruh ukuran perusahaan terhadap pengeluaran zakat pada bank umum syariah di Indonesia.

\section{LANDASAN TEORI}

Zakat dari badan usaha sering dianalogikan dengan zakat perdagangan, menurut pemikiran Abu Ishaq Asy-Syatibi yang berfatwa "Zakat perusahaan bagian dari memproduksi kemudian menjual kembali, atau memproduksi kemudian 
mengolahnya kembali sebagai komoditas perdagangan, dengan demikian zakatnya wajib dikeluarkan dari kepemilikan berupa stok barang yang akumulasi dengan harga penjualan apabila stok tersebut telah mencapai hisabnya. Hukumnya adalah sama seperti zakat perdagangan" (Asnaini, 2008). Zakat tidak sekedar anjuran namun merupakan kewajiban yang mengikat baik menurut hukum negara dan juga menurut syariah, Didalam Al-qur'an zakat difirmankan Allah SWT sebanyak 32 kali yang tersebar dalam Al-Qur'an.

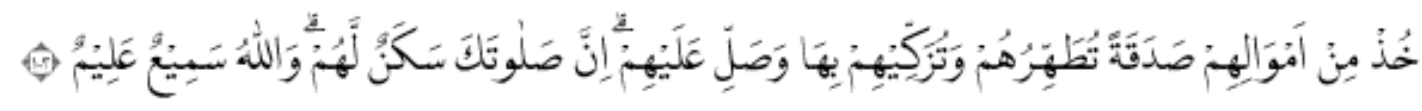

Ambillah zakat dari sebagian harta mereka, dengan zakat itu kamu membersihkan dan mensucikan mereka dan berdoalah untuk mereka. Sesungguhnya doa kamu itu (menjadi) ketenteraman jiwa bagi mereka. Dan Allah Maha Mendengar lagi Maha Mengetahui. (Q.S At-Taubah:103)

Zakat perbankan syariah merupakan zakat yang hanya dikeluarkan dari pihak bank sendiri dengan batas haul zakat dan batas nisabnya 85 gram emas. Perhitungan zakat perusahaan yaitu 2,5\% dari laba yang diperoleh setelah dikurangi beban. Zakat perusahaan terdiri dari zakat internal (laba perusahaan), dan eksternal yaitu zakat pegawai, dan zakat induk bank (nasabah). Zakat badan usaha tidak dijelaskan secara spesifik dan terperinci faktor yang menjadi penentu dalam besaran zakat yang dikeluarkan. Namun, rasio keuangan bersifat umum dan dapat digunakan sebagai informasi manajemen, pembuat kebijakan, dan sebagai media bukti yang konkrit kondisi perusahaan yang dapat dinilai oleh stakeholder. Apabila kondisi keuangan suatu perusahaan dalam keadaan baik maka sejatinya perusahaan tersebut dalam keadaan baik pula secara laporan kinerja, manajemen, dan prospek keuntungan. Dengan mengingkatnya keuntungan suatu usaha maka akan berdampak pula terhadap pengeluaran kewajiban zakat pada suatu badan usaha.

Rasio keuangan atau profitabilitas digunakan mengukur efektivitas manajemen secara keseluruhan yang dilihat melalui tingkat keuntungan yang diperoleh suatu kegiatan perusahaan berupa investasi dan penjualan (Fahmi, 2012). Ruang lingkup. Penelitian ini menggunakan informasi dari rasio keuangan perbankan yang terdiri dari ROA, ROE, dan ukuran perusahaan menjadi dasar mengukur seberapa besar total asset pada setiap BUS di Indonesia. Penelitian yang mengkaji mengenai zakat perusahaan diantaranya Santoso (2019) Menemukan bahwa ROA dan ukuran perusahaan memiliki pengaruh dari zakat BUS. Utari, Monoarfa, \& Ninglasari (2019) menemukan bahwa ROA tidak berpengaruh terhadap zakat BUS sedangkan faktor lain yang digunakan yaitu ROE dan ukuran perusahaan berpengaruh terhadap zakat BUS. Rahmawati (2018) Menemukan rasio profitabilitas dan ukuran DPS tidak berpengaruh terhada zakat BUS. Namun ukuran perusahaan cenderung memiliki pengaruh terhadap zakat BUS. Amamillah (2017) Menemukan bahwa ukuran perusaaan dan ROA berpengaruh terhadap pengeluaran zakat BUS. Abd Samad, Said, Kamarulzaman, Mahshar, \& Normaya (2015) Menemukan ROA, ROE, dan NPM tidak signifikan terhadap pembayaran zakat. Sedangkan total aset sebagai ukuran kinerja perbankan islam di Malaysia memiliki pengaruh signifikan terhadap pembayaran zakat.

Penelitian ini berbeda dengan penelitian terdahulu sebelumnya serta penelitian ini memiliki nilai kebaruan dalam hal berupa: (1) objek penelitian pada bank umum 
syariah yang hanya secara konsisten dama berzakat (2) penelitian menerangkan dan mengkaji zakat internal perusahaan sebagai pengukuran dalam zakat perusahaan (3) perhitungan dalam model regresi menggunakan it-1 dimana menandakan bahwa zakat yang diambil bukan berasal dari akumulasi tahunan akan tetapi zakat dapat dikeluarkan ketika mencapai haul dan nisab.

\section{METODE PENELITIAN}

Penelitian ini menggunakan metode deskriptif kuantitatif dan analitis. Teknik pengumpulan data adalah teknik documenter, data diperoleh dari situs www.bankmuamalat.co.id, www.bnisyariah.go.id, www.brisyariah.go.id, dan www.syariahmandiri.co.id berupa data tahunan dalam kurun waktu 2011 - 2019 dengan jumlah 36 observasi. Penelitian ini menggunakan zakat internal sebagai independen variabel (Y): Sejumlah harta perusahaan untuk memenuhi kewajibannya setelah mencapai batas minimum zakat, satuan jutaan rupiah. Sedangkan variabel dependen nya adalah ROA $\left(\mathrm{X}_{1}\right)$ : Rasio yang digunakan menilai tingkat pengembalian total aset yang dimiliki oleh perusahaan, satuan persen. ROE (X2): Rasio yang digunakan menilai ukuran pendapatan yang diterima atas modal yang telah di investasikan, satuan persen. Ukuran perusahaan $\left(\mathrm{X}_{3}\right)$ : Suatu skala yang dapat mengklasifikasikan ukuran perusahaan dengan berbagai cara; total aset, ukuran panjang, dan nilai pasar saham, satuan jutaan rupiah.

\section{Model}

Tahap awal pengujian melakukan asumsi klasik dari model yang terpilih yaitu Fixed Effect Model (FEM). Uji asumsi klasik wajib terpenuhi guna mendapatkan hasil terbaik dalam regresi linier berganda (Ghozali, 2013). Dalam penelitian ini, uji normalitas tidak dilakukan, uji normalitas hanya dilakukan apabila jumlah observasi kurang dari 30 sedangkan penelitian ini menggunakan observasi sebanyak 36. Jika jumlah observasi lebih dari 30 maka tidak diperlukan uji normalitas karena distribusi sampling error term mendekati normal (Ajija dkk 2011). Adapun pengujian asumsi klasik yang digunakan dalam penelitian ini adalah (1) Uji multikolinieritas digunakan mendeteksi adanya variabel masalah korelasi antara variabel yang digunakan dalam suatu penelitian, (2) Uji heteroskedastisitas bertujuan menguji suatu model regresi jika terdapat ketidaksamaan variance dari residual dari satu pengamatan kepengamanatan lainnya, (3) Uji autokorelasi berguna untuk mengamati adanya korelasi antara variabel pengganggu pada suatu observasi ke observasi sebelumnya.

\section{Analisis Regresi Data Panel}

Penentuan metode estimasi model regresi dengan menggunakan data panel dapat dilakukan melalui tiga pendekatan yaitu, Common Effect Model, Fixed Effect Model, Random Effect Model. Sebelum menentukan model terbaik akan dilakukan pengujian untuk menentukan model Common Effect (OLS) atau Fixed Effect yang paling tepat digunakan dalam mengestimasi data panel dengan Chow test, pengujian statistik untuk memilih apakah model Fixed Effect atau Random Effect yang paling tepat digunakan dengan Hausman test, dan pengujian statistik untuk memilih apakah model common Effect atau Random Effect yang paling tepat digunakan dengan Lagrange Multiplier.

Model regresi data panel yang digunakan dalam penelitian ini dapat di tuliskan sebagai berikut:

$$
\operatorname{LnY}_{\mathrm{it}-\mathrm{l}}=\beta_{0 \mathrm{i}}+\beta_{1} \mathrm{ROA}_{\mathrm{it}}+\beta_{2} \mathrm{ROE}_{\mathrm{it}}+\beta_{3} \mathrm{UKP}_{\mathrm{it}}+\varepsilon_{\mathrm{it}}
$$


Keterangan:

Ln = Logaritma Natural

$\mathrm{Y}_{\mathrm{it}-\mathrm{l}} \quad=$ Zakat $(\mathrm{Haul})$

$\beta_{0 \mathrm{i}} \quad=$ Intersep model pada unit observasi ke I

$\beta_{1-} \beta_{3}=$ Koefisien

$$
\begin{aligned}
\text { ROA } & =\text { Return On Asset } \\
\text { ROE } & =\text { Retunr On Equity } \\
\mathrm{UKP} & =\text { Ukuran Perusahaa } \\
\varepsilon & =\text { Error term } \\
\mathrm{i} & =\text { Bank Umum Syariah } \\
\mathrm{t} & =\text { Periode }
\end{aligned}
$$

\begin{tabular}{|c|c|c|c|}
\hline \multicolumn{4}{|c|}{ Redundant Fixed Effects Tests } \\
\hline Effects Test & Statistic & d.f. & Prob. \\
\hline Cross-section F & 6.6894 & $(3,29)$ & 0.0014 \\
\hline Cross-section Chi-square & 18.9329 & 3 & 0.0003 \\
\hline \multicolumn{4}{|c|}{ Correlated Random Effects - Hausman Test } \\
\hline Test Summary & $\begin{array}{l}\text { Chi-Sq. } \\
\text { Statistic }\end{array}$ & Chi-Sq. d.f. & Prob. \\
\hline Cross-section random & 20.0682 & 3 & 0.0002 \\
\hline
\end{tabular}

\section{HASIL DAN PEMBAHASAN}

\section{Pemilihan Model Regresi Data Panel}

Tabel 1: Pemilihan model

Sumber: Hasil Eviews 9 (diolah, 2021)

Berdasarkan hasil uji chow maka dapat diketahui bahwa nilai Cross-section $\mathrm{F}$ adalah $0.0014<0.05$ sebagai taraf signifikasinya artinya $\mathrm{H}_{0}$ ditolak. Dengan demikian dari hasil uji chow maka model yang dipilih sebagai model terbaik adalah FEM. Sedangkan hasil uji hausman maka dapat diketahui bahwa nilai Cross-section random adalah $0.0002<0.05$ sebagai taraf signifikasinya artinya $\mathrm{H}_{0}$ ditolak. Dengan demikian dari hasil uji hausman maka model yang dipilih sebagai model terbaik adalah FEM. Setelah melakukan uji chow dan uji hausman maka dapat disimpulkan bahwa model yang terbaik yang digunakan dalam penelitian ini adalah FEM. Dengan demikian tidak perlu melakukan pengujian selanjutnya dalam menentukan model terbaik yakni uji lagrange multiplier.

Uji Asumsi Klasik

Tabel 2: Uji Asumsi Klasik

\begin{tabular}{cccc}
\hline & \multicolumn{3}{c}{ Uji Multikolinieritas } \\
\hline & ROA & ROE & UKP \\
\hline ROA & 1 & 0.6437 & -0.1698 \\
\hline ROE & 0.6437 & 1 & 0.0512 \\
\hline UKP & -0.1698 & 0.0512 & 1 \\
\hline
\end{tabular}




\begin{tabular}{ccccc}
\hline \multicolumn{5}{c}{ Uji Heteroskedastisitas } \\
\hline Variable & Coefficient & Std. Error & t-Statistic & Prob. \\
\hline C & -0.8805 & 1.5669 & -0.5619 & 0.5781 \\
\hline ROA & -0.0576 & 0.1210 & -0.4769 & 0.6367 \\
\hline ROE & -0.0037 & 0.0107 & -0.3439 & 0.7332 \\
\hline TA & 0.0746 & 0.0892 & 0.8366 & 0.4090 \\
\hline \multicolumn{7}{r}{ Durbin-Watson stat } & Uji Autokolerasi & \\
\hline
\end{tabular}

Sumber: Hasil Eviews 9 (diolah, 2021)

Berdasarkan hasil uji multikolinieritas bahwa nilai korelasi dari antar variabel lebih kecil dari 0.8 dapat disimpulkan bahwa antara variabel independen tidak mengandung multikolinieritas. Hasil uji heteroskedastisitas dapat disimpulkan $\mathrm{H}_{0}$ diterima dan tidak terdapat heteroskedastisitas. Hal ini dapat dilihat dari nilai probabilitas pada variabel ROA sebesar $0.4062>0.05$, ROE sebesar $0.2728>0.05$, dan UKP sebesar $0.7364>0.05$ dimana nilai alpha sebagai taraf signifikansi. Sedangkan nilai DW yang dibandingan DW table dengan DW hitung disimpulkan nilai $\mathrm{dl} \leq \mathrm{d} \leq 4$-du atau $1.328<1.797<2.342$ maka maka tidak terjadi gejala autokerelasi.

\section{Analisis Regresi Data Panel}

Setelah melakukan estimasi yang terdapat pada model maka model yamg terpilih adalah fixed effect, dimana lebih baik dalam menjelaskan model regresi data panel dalam penelitian ini.

Tabel 3: Fixed Effect Model

\begin{tabular}{crrrr}
\hline Variable & Coefficient & Std. Error & t-Statistic & Prob. \\
\hline C & -10.8122 & 3.9639 & -2.7276 & 0.0107 \\
\hline ROA? & 0.4926 & 0.2508 & 1.9645 & 0.0591 \\
\hline ROE? & 0.0407 & 0.0179 & 2.26843 & 0.0309 \\
\hline UKP? & 1.0737 & 0.2257 & 4.7565 & 0.0000 \\
\hline \multicolumn{5}{c}{ Fixed Effects (Cross) } \\
\hline _BSM--C & -0.1405 \\
\hline -BNIS--C & 0.2658 \\
\hline -BRIS--C & 0.6324 \\
\hline _MUAMALAT--C & -0.7577 \\
\hline Cross-section fixed (dummy variables) \\
\hline Adjusted R-squared & 0.6853 \\
\hline Prob(F-statistic) & 0.0000 \\
\hline
\end{tabular}

Sumber: Hasil Eviews 9 (diolah, 2021)

Interpretasi hasil dari estimasi persamaan regresi diatas yaitu sebagai berikut: (a) Jika pengaruh ROA, ROE, dan ukuran perusahaan adalah nol maka pengeluaran zakat akan mengalami penurunan sebesar 10,81\% (b) Jika variabel independen lainnya yaitu ROE atau $\mathrm{X}_{2}$ dan UKP atau $\mathrm{X}_{3}$ tetap dan jika ROA meningkat sebesar $1 \%$ maka pengeluaran zakat akan mengalami peningkatan sebesar 0,49\% (c) Jika variabel independen lainnya yaitu ROA atau $X_{1}$ dan UKP atau $X_{3}$ tetap dan jika ROE meningkat sebesar 1\% maka pengeluaran zakat akan mengalami peningkatan sebesar 0,04\% (d) Jika variabel independen lainnya yaitu ROA atau $X_{1}$ dan ROE atau $X_{2}$ tetap dan jika UKP meningkat sebesar $1 \%$ maka pengeluaran zakat akan mengalami peningkatan sebesar 1,07\%. Koefisien determinasi regresi yaitu Adj- $\mathrm{R}^{2}$ sebesar 0,6853 maka dapat disimpulkan bahwa kemampuan variabel independen dan variabel dependen sebesar 
$68,53 \%$ dan masih terdapat $31,47 \%$ yang terdapat pada variabel independen diluar model.

\section{Return on Asset Terhadap Pengeluaran Zakat Bank Umum Syariah}

Berdasarkan hasil analisis uji t-statistik yang telah dilakukan dalam model, ROA tidak berpengaruh signifikan terhadap zakat BUS karena nilai probabilitas t-statistik lebih besar dari taraf signifikan. Hal ini menunjukkan bahwa meningkatnya ROA belum tentu berpengaruh terhadap pengeluaran zakat masing-masing BUS karena dipengaruhi oleh berbagai faktor lain yang ada pada perbankan syariah.

Penelitian ini sejalan dengan hasil dari penelitian Aisyah (2020) yang menyatakan bahwa ROA secara parsial tidak berpengaruh signifikan terhadap pengeluaran zakat karena nilai probabilitas lebih besar dari taraf signifikan. Penelitian yang dilakukan Widiastuti (2018) juga menyatakan bahwa ROA tidak berpengaruh signifikan terhadap pengeluaran zakat karena pertumbuhan aset dan pembiayan pada perbakan syariah mengalami penurunan dari periode sebelumnya yang disebabkan meningkatnya inflasi pada tahun 2013. Penelitian yang dilakukan Rahmawati (2018) menyatakan bahwa ROA tidak berpengaruh signifikan terhadap pengeluaran zakat disebabkan bank umum syariah sebagai suatu kesatuan usaha yang berlandaskan prinsip syariah maka memiliki tanggungjawab baik secara horizontal dan vertikal. Penelitian lain yaitu Santoso (2019) mengungkapkan bahwa ROA berpengaruh signifikan terhadap pengeluaran zakat dikarekan semakin besar tingkat ROA maka kemampuan perusahaan dalam memanfaatkan aktiva perusahaan sangat baik dalam menghasilkan profit. Namun penelitian ini memiliki keterbatasan yaitu hasil zakat yang diperoleh dari berbagai bersumber internal dan eksternal perusahaan.

Return on Asset merupakan pengukuran yang digunakan untuk menilai kemampuan perusahaan dalam menghasilkan laba dengan memanfaatkan semua aktiva perusahaan. Namun tingkat keuntungan dalam perusahaan tentu dipengaruhi oleh berbagai faktor baik yang dapat dikendalikan dan yang tidak dapat dikendalikan. Diantaranya banyak bank umum syariah yang tidak melakukan pembayaran zakat secara konsisten, pihak perusahaan lebih mengutamakan kewajiban pajak sehingga merasa tidak perlu lagi membayar zakat, dan adanya argument yang menyatakan bahwa perusahaan tidak perlu lagi membayar zakat. Karena zakat adalah kewajiban setiap individu saja dan zakat cukup dikeluarkan oleh pemilik saham perusahaan dengan menggunakan nama pribadi bukan perusahaan (Abd Samad, Said, Kamarulzaman, Mahshar, \& Normaya, 2015).

\section{Return on Equity Terhadap Pengeluaran Zakat Bank Umum Syariah}

Berdasarkan hasil analisis uji t-statistik yang telah dilakukan dalam model, ROE memiliki pengaruh signifikan terhadap zakat BUS karena nilai probabilitas t-statistik lebih kecil dari taraf signifikan. Artinya semakin tinggi tingkat ROE yang menggambarkan profitabilitas suatu perusahaan maka memiliki kinerja yang baik. Disamping itu tingginya tingkat ROE akan berdampak pula terhadap besaran zakat yang dikeluarkan. Hal ini dikarenakan dalam perhitungan zakat suatu badan usaha berdasarkan pada besaran laba usaha yang diperoleh setelah dikurangi dengan beban.

Penelitian ini sejalan dengan hasil penelitian oleh Utari, Monoarfa, \& Ninglasari, (2019) ROE memiliki pengaruh signifikan terhadap zakat apabila laba yang tersedia bagi pemilik perusahaan besar akan berdampak kepada kenaikan zakat perusahaan. Hal ini dikarenakan bahwa saham perusahaan harus wajib zakat sebagai zakat 
perusahaan. Penelitian lain Maulana (2019) bahwa ROE memiliki pengaruh signifikan terhadap pengeluaran zakat karena ekuitas yang besar akan memudahkan perusahaan dalam menggunakan sumber daya untuk memaksimalkan keuntungan dan mendapatkan kepercayaan dari investor. Adapun penelitian yang dilakukan oleh Abd Samad, Said, Kamarulzaman, Mahshar, \& Normaya (2015) menyatakan bahwa ROE tidak berpengaruh terhadap pengeluaran zakat karena jumlah zakat perusahaan yang dikeluarkan oleh bank syariah di Malaysia tidak sama sekali berdasarkan tingkat pengembalian modal perusahaan.

Temuan dalam penelitian ini sangat berkaitan dengan konsep teoritis dan didukung oleh fakta empiris dari penelitian sebelumnya maka dapat disimpulkan bahwa ROE memiliki pengaruh signifikan terhadap pengeluaran zakat. ROE merupakan rasio untuk melihat perbandingan laba setelah pajak dengan modal usaha. Hasil perbandingan rasio menggambarkan besarnya laba usaha yang diterima perusahaan dalam mengelola modal yang diinvestasikan. Artinya ROE merupakan ukuran yang paling terpenting dalam merefleksikan kepentingan kepemilikan (Manurung, 2004).

\section{Ukuran Perusahaan Terhadap Pengeluaran Zakat Bank Umum Syariah}

Berdasarkan hasil analisis uji t-statistik yang telah dilakukan dalam model, ukuran perusahaan yang menggambarkan total aset BUS berpengaruh signifikan terhadap pengeluaran zakat. Semakin besar total aset pada BUS cenderung lebih bebas dalam mengambil kebijakan termasuk kewajiban zakat pada perbakan syariah. Pandangan ini berbeda jika total aset pada BUS yang kecil maka tentu banyak pertimbangan dalam hal setiap pengeluaran perbakan syariah.

Hasil penelitian ini sejalan dengan penelitian Utari, Monoarfa, \& Ninglasari (2019) bahwa jika jumlah ukuran perusahaan besar maka zakat perusahaan akan berpotensi meningkat. Hal ini dikarenakan besarnya total aset merupakan hasil dari proses kegiatan usaha dalam mendapatkan profit. Penelitian lain yaitu oleh Abd Samad, Said, Kamarulzaman, Mahshar, \& Normaya (2015) yang menjelaskan bahwa ukuran perusahaan berpengaruh signifikan terhadap jumlah zakat yang dikeluarkan untuk bank syariah di Malaysia. Berdasarkan temuan ini yang berkaitan dengan konsep teoritis dan didukung oleh fakta empiris dari penelitian sebelumnya maka dapat disimpulkan bahwa ukuran perusahaan berpengaruh signifikan terhadap pengeluaran zakat BUS di Indonesia.

Praktek usaha BUS seharusnya tidak hanya berorientasi pada keuntungan semata namun berorientasi falah. Adanya falah oriented, bank syariah dituntut juga berorientasi pada zakat, yang dapat dilihat dari seberapa besar kemampuan bank syariah untuk mengeluarkannya zakat (Jaelani, 2016).

\section{KESIMPULAN}

Berdasarkan pembahasan hasil penelitian yang telah dilakukan, maka dapat diperoleh kesimpulan dalam penelitian ini yaitu ROA berpengaruh positif dan tidak signifikan terhadap pengeluaran zakat BUS di Indonesia. Hal ini disebabkan tingkat ROA yang mengalami fluktuatif yang cenderung mengalami kenaikan akan tetapi tidak menjadi faktor utama dalam melakukan pengeluaran zakat BUS di Indonesia. ROE memiliki pengaruh positif dan signifikan terhadap pengeluaran zakat BUS di Indonesia. Hal ini disebabkan dalam setiap operasional usaha BUS total profit yang telah mencapai haul dan telah dikurangi dengan modal beserta kewajibannya maka sudah dikenakan zakat. Semakin besar tingkat ROE maka pengembalian modal yang diberikan kepada pemegang saham akan meningkat dan diikuti pula zakat yang 
dikeluarkan juga meningkat. Meningkatnya pengembalian yang diterima pemegang saham maka wajib pula dikenai zakat. Ukuran perusahaan memiliki pengaruh positif dan signifikan terhadap pengeluaran zakat BUS di Indonesia. Dengan demikian jika ukuran perusahaan BUS besar maka cenderung lebih leluasa dalam intervensi pengeluaran zakat.

\section{DAFTAR PUSTAKA}

Abd Samad, K., Said, R., Kamarulzaman, M. H., Mahshar, M., \& Normaya, I. (2015). Exploring the Zakat Payment and Firm's Performance of Islamic Banks in Malaysia. In The 6th International Conference on Governance, Fraud, Ethics and Social Responsibility.

Aisyah, A. N. (2020). Pengaruh Return on Asset (ROA), Return On Equity (ROE) dan Net Profit Margin (NPM) Terhadap Pengeluaran Zakat dengan Ukuran Perusahaan Sebagai Variabel Moderasi Pada Bank Umum Syariah Di Indonesia Tahun 2014-2019. (Doctoral dissertation, IAIN Salatiga)

Ajija, Shochrul R, dkk. (2011). Cara Cerdas Menguasai Eviews.Jakarta: Selemba Empat.

Arif, H. M., Alwi, K., \& Tahir, A. M. (2011). Factors Influence Company Towads Zakat Payment: An Explanatory Studies. In Second International Conference on Business and Economic Research (2nd ICBER 2011) Proceeding.

Al Qaradhawi, Y. (2007). Figh Al Zakah. Jakarta: Pustaka Nasional

Amamillah, M. H. (2017). Pengaruh Return On Asset (ROA) dan ukuran perusahaan terhadap pengeluaran zakat bank umum syariah di Indonesia Tahun 20102016 (Bachelor's thesis, UIN Syarif Hidayatullah Jakarta: Fakultas Ekonomi dan Bisnis, 2017).

Ariawaty, R. N., \& Evita, S. N. (2018). Metode Kuantitatif Praktis. Bandung: PT. Bima Pratama Sejahtera.

Asnain. (2008). Zakat Produktif Dalam Perspektif Hukum Islam. Yogyakarta: Pustaka Pelajar.

Basuki, A. T., \& Prawoto, N. (2016). Analisis Regresi Dalam Penelitian Ekonomi Dan Bisnis. Depok: Grafindo Persada.

Bawono, A. (2006). Multivariate Analisis Analyze Dengan SPSS. Salatiga: Stain Salatiga Press.

Departemen Agama RI. (2009). Al Qur'an dan Tafsirannya. Jakarta: Lembaga Percetakan Al-Qur'an Departemen Agama.

Fahmi, I. (2012). Analisis Laporan Keuangan. Cetekan Ke-2. Bandung: Alfabeta.

Ferdinand, A. (2014). Metode Penelitian Manajemen. Semarang: BP Universitas Diponogoro.

Firmansyah, I., \& Rusydiana, A. S. (2013). Pengaruh Profitabilitas Terhadap Pengeluaran Zakat Pada Bank Umum Syariah Di Indonesia Dengan Ukuran Perusahaan Sebagai Variabel Moderasi. Liquidity, 2(2), 110-116.

Furchan, A. (2004). Pengantar Penelitian Dalam Pendidikan. Yogyakarta: Pustaka Pelajar.

Ghazali, I. (2013). Aplikasi Analisis Multivariated Engan Program IBM SPSS 23. Semarang: Universitas Diponegoro.

Gujarati. (2012). Dasar-dasar Ekonometrika. Jakarta: Selemba Empat.

Jaelani, A. (2016). Zakat Accounting: Metaphor and Accounting Treatment For Business Organization. MPRA Paper 18.

Kasmir. (2003). Bank dan Lembaga Keuangan Lainya. Jakarta: Grafindo Persada. 
Kuncoro, M. (2012). Metode Kuantitatif: Teori dan Aplikasi Untuk Bisnis \& Ekonomi. Yogyakarta: PP STIM YKPN.

Manurung, M. (2004). Uang, Perbankan, dan Ekonomi Moneter (Kajian Kontekstual Indonesia). Jakarta: FEUI.

Martono, N. (2011). Metode Penelitian Kuantitatif. Jakarta: Grafindo Persada.

Maulana, R. (2020). Pengaruh Rasio Profitabilitas Terhadap Zakat Perusahaan (Studi pada Bank Umum Syariah Yang Beroperasi Di Banda Aceh) (Doctoral dissertation, UIN AR-RANIRY).

Muhammad. (2005). Manajemen Bank Syariah. Yogyakarta: UUP AMPYKPN

Priyatno, D. (2010). Cara Kiat Belajar Analisis Data Dengan SPSS 20. Yogyakarta: CV. Andi Offset.

Putrie, R. D. N., \& Achiria, S. (2019). Pengaruh Rasio Profitabilitas Terhadap Zakat Perusahaan Pada Bank Devisa Syariah. Al-Azhar Journal of Islamic Economics, 1(1), 38-48.

Rahmawati, I. C. F., \& Dita, A. (2018). Pengaruh Profitabilitas, Ukuran Perusahaan, Dan Ukuran Dewan Komisaris Terhadap Pengeluaran Zakat (Studi Empiris Pada Bank Umum Syariah di Indonesia Tahun 2011-2017)(Doctoral dissertation, IAIN Surakarta).

Ridho Maulana, M. (2019). Pengaruh Rasio Profitabilitas Terhadap Pengungkapan Zakat Perbankan Syariah Dengan Ukuran Perusahaan Sebagai Variabel Moderasi (Doctoral dissertation, Universitas Ahmad Dahlan).

Santoso, I. N. (2019). Pegaruh Return On Asset (Roa) Dan Ukuran Perusahaan Terhadap Pengeluaran Zakat Bank Umum Syariah di Indonesia (Periode 20122017) (Doctoral dissertation, UIN Raden Intan Lampung).

Santoso, S. (2001). Buku Latihan SPSS Statistik Parametrik. Jakarta: PT. ELEK Media.

Sugiyono. (2006). Metode Penelitian Bisnis. Bandung: CV Alvabeta.

Sumiyati, A. (2019). Pengaruh Profitabilitas Terhadap Pengeluaran Zakat Dengan Ukuran Perusahaan Sebagai Variabel Moderasi Pada Bank Umum Syariah di Indonesia. Jpak: Jurnal Pendidikan Akuntansi Dan Keuangan, 5(1), 1-10.

Wahyudi, S. T., (2016). Konsep dan Terapan Ekonomitrika Menggunakan E-views. Jakarta: Grafindo Persada.

Utari, R., Monoarfa, H., \& Ninglasari, S. Y. (2019). Factors Influencing Corporate Zakat Expenditure (Case Study of Islamic Banks in Indonesia Period 20152017). KnE Social Sciences, 413-427.

Winarno, W. (2009). Analisis Ekonomitrika dan Statistika Dengan Eviews. Edisi Kedua. Yogyakarta: Sekolah Tinggi Ilmu Manajemen YKPN.

Triyuwono, I. (1997). "Akuntansi syari'ah" dan koperasi: mencari bentuk dalam bingkai metafora amanah. Jurnal Akuntansi dan Auditing Indonesia, Vol. 1 No. 1:1-46.

Zaitun, S. (2000). Analisis Pengaruh Rasio Profitabilitas Terhadap Zakat Pada PT. Bank Muamalat Indonesia (Doctoral dissertation, program Pascasarjana Universitas Diponegoro). 